\title{
The effect of fish oil in calf diets on the fatty-acid content of Musculus thoracis intramuscular fat
}

\author{
M. Zymon ${ }^{1}$, J.A. Strzetelski ${ }^{1,3}$ and J. Kowalczyk ${ }^{2}$ \\ ${ }^{1}$ National Research Institute of Animal Production \\ 32-083 Balice, Poland \\ ${ }^{2}$ The Kielanowski Institute of Animal Physiology and Nutrition, Polish Academy of Sciences \\ 05-110 Jabtonna, Poland
}

\begin{abstract}
The experiment examined the effect of fish oil in calf diets on the fatty acid profile in the fat of 16 Black-and-White bull calves allotted to 2 groups of 8 animals from 7 to 90 days of age. The animals of the control group were given ad libitum a diet consisting of ground cereals, soyabean meal and minerals supplemented for the experimental group (FO) with $4 \%$ of fish oil. At 90 days of age the calves were slaughtered and samples of meat from Musculus thoracis were analysed for fatty acid content. Differences in total fat appeared to be not significant $(\mathrm{P}>0.05)$ between the groups. A significant increase in n-3 FA and decrease in the n-6/n-3 ratio was found in the meat fat of group FO animals. Supplementation of the diet with fish oil increased the proportion of $C_{20: 1} n-9, C_{20: 4} n-3, C_{20: 5}$ $n-3, C_{22: 4} n-6, C_{22: 5} n-3$ and $C_{22: 6} n-3$, whereas the proportions of $C_{18: 0}$ decreased significantly.
\end{abstract}

KEY WORDS: calf, fish oil, Musculus thoracis, eicopentasenoicate, docosahexaenoicate

\section{INTRODUCTION}

The long-chain n-3 fatty acids, eicozapentaenoic acid (EPA) and docosahexaenoic acid (DHA), are required for many metabolic processes in humans and play an important role in prevention of heart disease and cancer in humans (Givens, 2000). The richest source of EPA and DHA are fish oils.

It has been reported that supplementing fish oil to animal diets appears to be a way of significantly increasing the n-3 PUFA content of meat (Ashes et al., 1992). The aim of the present study was to determine the effect of fish oil in calf diets on the fatty-acid profile of meat fat.

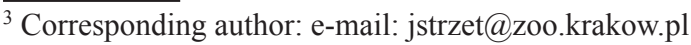




\section{MATERIAL AND METHODS}

The experiment was carried out on 16 Black-and-White bull calves, randomly allotted into two feeding groups of 8 animals. Calves of the control group (C) were fed ad libitum a concentrate mixture containing, \%: ground barley 40.5 , ground wheat 27-30.5, wheat bran 10-13, soyabean meal 13-15.5, minerals 3, supplemented with $4 \%$ fish oil for the experimental group (FO). Mixture compositions, daily rations, energy and protein value of feeds were formulated according to IZ-INRA (2001) standards. The calves were fed individually from day 7 to 90 of life, for the first 56 days they also received a milk replacer. At the end of the experiment the calves were slaughtered, samples of meat from the Musculus thoracis were taken for fat analysis. Proximate analysis of feeds and meat components was carried out according to AOAC (1990) methods, the fatty-acid profile was estimated in extracted fat using gas chromatography (Varian 3400, $105 \mathrm{~m}$ column). The results were analysed using the one-way analysis of variance procedure of the SAS (Enterprise Guide, 2002) package. The differences were assumed to be not significant $(\mathrm{P}>0.05)$.

\section{RESULTS}

The nutrient and fatty-acid contents and profiles in feeds are given in Table 1. Table 1. Nutrient and fatty-acid contents and profiles in feeds

\begin{tabular}{lcrr}
\hline \multirow{2}{*}{ Item } & Milk & \multicolumn{2}{c}{ Mixtures } \\
\cline { 2 - 4 } & replacer & control & fish oil \\
\hline Dry matter, g kg-1 & 97.33 & 87.45 & 88.66 \\
Crude protein, g kg-1 DM & 19.95 & 14.10 & 17.41 \\
Fat, g kg ${ }^{-1}$ DM & 19.86 & 1.62 & 4.99 \\
Ash, g kg DM & 8.07 & 4.56 & 5.29 \\
& & & \\
Fatty acids, \% of total fat & & & \\
C14 & 3.96 & 0.29 & 5.16 \\
C16 & 30.68 & 17.35 & 26.39 \\
C18 & 4.10 & 1.67 & 3.22 \\
C18:1 & 31.29 & 15.44 & 27.06 \\
C18:2 n-6 & 16.71 & 58.94 & 25.41 \\
C18:3 n-3 & 0.57 & 5.16 & 1.35 \\
C20:5 n-3 EPA & 0.00 & 0.00 & 1.33 \\
C22:6 n-6 DHA & 0.00 & 0.14 & 3.10 \\
SFA & 50.98 & 19.49 & 35.70 \\
UFA & 48.93 & 80.41 & 64.26 \\
PUFAn-6/n-3 & 29.40 & 11.12 & 4.45 \\
\hline
\end{tabular}

Differences in final body weight, average daily gain or concentrate intake between groups (Table 2) did not reach statistical significance $(\mathrm{P}>0.05)$.

Supplementation of the diet with fish oil had no significant $(\mathrm{P}>0.05)$ effect on total fat, SFA, UFA, PUFA content but resulted in a significant increase in $n-3$ 
PUFA ( $P=0.003)$. Fat in the meat from group FO animals contained more $C_{20: 1} n-9$, $\mathrm{C}_{20: 4} \mathrm{n}-3$, EPA, DHA and $\mathrm{C}_{22: 5} \mathrm{n}-3$ and DHA and a lower n-6/n-3 ratio compared with the fat from the control group $(\mathrm{P}<0.05)$. In the experimental group, significant decreases in the proportions of $\mathrm{C}_{22: 4} \mathrm{n}-6$ and $\mathrm{C}_{18: 0}$ were also found (Table 3 ).

Table 2. Fattening parameters of calve $\mathrm{s}$

\begin{tabular}{lrrr}
\hline \multirow{2}{*}{ Item } & \multicolumn{2}{c}{ Groups } & \multirow{2}{*}{ SE } \\
\cline { 2 - 3 } & \multicolumn{1}{c}{ control } & \multicolumn{1}{c}{$\mathrm{FO}$} & \\
\hline Initial body weight, $\mathrm{kg}$ & 42.81 & 48.75 & 1.92 \\
Final body weight, $\mathrm{kg}$ & 92.56 & 91.94 & 3.29 \\
Daily weight gain, $\mathrm{kg}$ & & & \\
$\quad$ from 7 to 56 day & 455.18 & 397.32 & 32.80 \\
$\quad$ from 7 to 90 day & 611.06 & 529.29 & 33.62 \\
Concentrate mixture intake, $\mathrm{kg}$ & 68.90 & 65.17 & 5.17 \\
Intake of mixture/kg of daily weight gain, $\mathrm{kg}$ & 1.39 & 1.48 & 0.07 \\
\hline
\end{tabular}

$\mathrm{P}>0.05$

Table 3. Fatty-acid composition of Musculus thoracis fat, \% of total fat

\begin{tabular}{|c|c|c|c|c|}
\hline \multirow{2}{*}{ Fatty acids } & \multicolumn{2}{|c|}{ Groups } & \multirow{2}{*}{ SE } & \multirow{2}{*}{$\mathrm{P}$} \\
\hline & $\mathrm{C}$ & $\mathrm{FO}$ & & \\
\hline $\mathrm{C}_{2}$ & 1.07 & 1.26 & 0.14 & 0.5 \\
\hline $\mathrm{C}_{16: 0}^{140}$ & 17.17 & 17.99 & 0.55 & 0.47 \\
\hline $\mathrm{C}^{16: 0}$ & 12.04 & 10.46 & 0.32 & 0.008 \\
\hline $\mathrm{C}_{18: 0}^{180}$ & 24.99 & 25.78 & 1.27 & 0.77 \\
\hline $\mathrm{C}_{18: 2}^{18: 1} \mathrm{n}-6$ & 18.86 & 15.66 & 0.99 & 0.11 \\
\hline$C_{18: 3}^{18: 2} n-3$ & 0.53 & 0.58 & 0.03 & 0.57 \\
\hline $\mathrm{C}^{18: 3}$ & 0.18 & 0.15 & 0.01 & 0.35 \\
\hline $\mathrm{C}_{20 \cdot 0}^{200} \mathrm{n}-9$ & 0.30 & 0.55 & 0.04 & 0.0001 \\
\hline$C^{20: 1} n-3$ & 0.08 & 0.97 & 0.15 & 0.0003 \\
\hline $\mathrm{C}_{20.5}^{20: 4} \mathrm{n}-3$ (EPA) & 0.38 & 2.75 & 0.44 & 0.003 \\
\hline$C_{22: 4}^{20: 5} n-6$ & 0.70 & 0.33 & 0.06 & 0.0009 \\
\hline$C_{22.5}^{22.4} n-3$ & 0.84 & 1.50 & 0.14 & 0.012 \\
\hline $\mathrm{C}_{22.6}^{22.3} \mathrm{n}-3$ (DHA) & 0.23 & 0.86 & 0.11 & 0.0009 \\
\hline $\mathrm{SF}^{22} \mathrm{~A}$ & 31.89 & 31.07 & 0.78 & 0.62 \\
\hline UFA & 57.15 & 58.10 & 0.46 & 0.32 \\
\hline PUFA & 29.20 & 28.73 & 1.70 & 0.90 \\
\hline PUFA n-3 & 2.06 & 6.66 & 0.79 & 0.0036 \\
\hline PUFA n-6 & 27.14 & 22.08 & 1.56 & 0.11 \\
\hline PUFA n-6/n-3 & 13.30 & 4.11 & 1.37 & $<0.0001$ \\
\hline
\end{tabular}

differences are not statistically significant at $\mathrm{P}>0.05$

\section{DISCUSSION}

In the present study, supplementing the diet with fish oil had no effect on growth performance and total fat content in meat, but highly increased the proportions of n-3 dietary fatty acids (EPA and DHA) in meat. Similar results were also reported by Jenkins and Kramer (1990). Ashes et al. (1992) suggests that ruminal microflora could not hydrogenate EPA and DHA to any significant extent when fish oil preparations were incubated with strained rumen liquor. Byers and Schelling (1988) 
reported that changes in dietary PUFA from fish oil in the rumen are slow because of limited hydrolysis of fats. A high increase in n-3 FA was also due to increased levels of $C_{20: 4} n-3$ and $C_{22: 5} n-3$, which are metabolites of $C_{18: 3} n-3$ in the synthesis of EPA and DHA. This suggests that ruminants may be able to synthesize EPA and DHA from their precursor of $\alpha$-linolenic acid, although the conversion efficiency is relatively low (Givens et al., 2000). PUFA n-6 tended to decrease, but the difference was not significant. However, the content of $\mathrm{C}_{22: 4} \mathrm{n}-6$ decreased as well as the ratio of $n-6 / n-3$ FA $(\mathrm{P}<0.001)$, which is advantageous from the human dietetic point of view. A decrease in stearic acid in group FO was observed $(\mathrm{P}<0.01)$, suggesting that EPA and DHA could bypass ruminal hydrogenation.

In can be concluded that feeding calves a diet supplemented with fish oil increases the supply fatty acids to the small intestine and influences the fatty acid composition of meat fat. Fish oil resulted in an increase in muscle long-chain n-3 FA content, a decrease in the $n-6 / n-3$ ratio, and improved nutritional value of veal for human consumption.

\section{REFERENCES}

AOAC, 1990. Association of Analytical Chemists. Official Methods of Analysis. $15^{\text {th }}$ Edition. Arlington, VA

Ashes J.R., Siebert B.D., Gulati S.K., Cuthbertson A.Z., Scott T.W., 1992. Incorporation of n-3 fatty acids of fish oil into tissue and serum lipids of ruminants. Lipids 27, 629-631

Byers F.M., Schelling G.T., 1988. Lipids in ruminant nutrition. In: D.C. Church (Editor). The Ruminant Animal: Digestive Physiology and Nutrition. Prentice Hall, Englewood Cliffs, N.J., pp. 298-312

Givens D.I., Cottrill B.R., Davies M., Lee P.A., Mansbridge R.J., Moss A.R., 2000. Sources of n-3 polyunsaturated fatty acids additional to fish oil for livestock diets - a review. Nutr. Abstr. Rev., Ser. B 70, 1-18

IZ-INRA, 2001. Standards for Cattle, Sheep and Goats Nutrition (in Polish). National Research Institute of Animal Production, Kraków (Poland)

Jenkins K.J., Kramer J.K.G., 1990. Effect of dietary horn oil and fish oil concentrate on lipid composition of calf tissues. J. Dairy Sci. 73, 2940-2951

\section{STRESZCZENIE}

\section{Wpływ oleju rybnego w żywieniu cieląt na profil kwasów tluszczowych tluszczu śródmięśniowego} Musculus thoracis

Doświadczenie przeprowadzono na 16 buhajkach rasy cb (2 grupy po 8 cieląt) od 7 do 90 dnia życia. Cielęta żywiono do woli mieszanką treściwą zawierającą śruty zbożowe, poekstrakcyjną śrutę sojowa, składniki mineralne, a w grupie doświadczalnej dodatkowo 4\% oleju rybnego. Do 56 dnia cielęta otrzymywały także preparat mlekozastępczy. W 90 dniu buhajki ubijano i pobierano próbki mięsa z Musculus thoracis. Dodatek oleju rybnego nie miał wpływu na ogólną zawartość tłuszczu, zwiększył natomiast zawartość EPA i DHA ( $<<0,003)$, a także ogólną zawartość PUFA n-3 w tłuszczu mięsa. Istotnemu obniżeniu uległ także wskaźnik n-6/n-3 ( $<<0,001)$. 